\title{
The FXG: A Presynaptic Fragile X Granule Expressed in a Subset of Developing Brain Circuits
}

\author{
Sean B. Christie, ${ }^{1 \star}$ Michael R. Akins, ${ }^{1 *}$ James E. Schwob, $^{2}$ and Justin R. Fallon ${ }^{1}$ \\ ${ }^{1}$ Department of Neuroscience, Brown University, Providence, Rhode Island 02912, and 2Department of Anatomy and Cellular Biology, Tufts University \\ Medical School, Boston, Massachusetts 02111
}

The loss of Fragile X mental retardation protein (FMRP) causes Fragile X syndrome, the most common inherited mental retardation and single gene cause of autism. Although postsynaptic functions for FMRP are well established, potential roles at the presynaptic apparatus remain largely unexplored. Here, we characterize the expression of FMRP and its homologs, FXR1P and FXR2P, in the developing, mature and regenerating rodent nervous system, with a focus on presynaptic expression. As expected, FMRP is expressed in the somatodendritic domain in virtually all neurons. However, FMRP is also localized in discrete granules (Fragile X granules; FXGs) in a subset of brain regions including frontal cortex, hippocampal area CA3 and olfactory bulb glomeruli. Immunoelectron microscopy shows that FMRP is localized at presynaptic terminals and in axons within these FXG-rich regions. With the exception of the olfactory bulb, FXGs are prominent only in the developing brain. Experiments in regenerating olfactory circuits indicate that peak FXG expression occurs 2-4 weeks after neurogenesis, a period that correlates with synapse formation and refinement. Virtually all FXGs contain FXR2P, while region-selective subsets harbor FMRP and/or FXR1P. Genetic studies show that FXR2P is essential for FXG expression, while FMRP regulates FXG number and developmental profile. These findings suggest that Fragile X proteins play a distinct, presynaptic role during discrete developmental epochs in defined circuits of the mammalian CNS. We propose that the neurological defects in Fragile X syndrome, including the autistic features, could be due in part to the loss of FMRP function in presynaptic compartments.

Key words: Fragile X syndrome; FMRP; FXR2P; olfactory system, axonal regeneration; synaptic plasticity

\section{Introduction}

Fragile X syndrome (FXS) is a synaptic disease that is the most common single gene cause of mental retardation and autism (O'Donnell and Warren, 2002; Pickett and London, 2005). In almost all cases, FXS is caused by silencing of the FMR1 gene and the resultant absence of its product, Fragile X mental retardation protein (FMRP). FXS presents as developmental delay at $\sim 2-3$ years of age. In affected patients, cognition is severely impaired resulting in mental retardation and dysfunctional executive control. Hyperactivity, seizures and hypersensitivity to sensory stimuli are also typical.

FMRP and its homologs, FXR1P and FXR2P, are RNAbinding proteins that are highly expressed in the developing brain. The best-characterized function of FMRP is in protein synthesis-dependent synaptic plasticity, which occurs at least in part postsynaptically. For example, FMRP levels are transiently elevated in dendrites of the visual cortex of dark-reared/lightexposed rats (Gabel et al., 2004) and both human FXS patients and mouse fmrl knock-outs display elongated dendritic spines.

Received Aug. 15, 2008; revised Dec. 5, 2008; accepted Dec. 23, 2008

This work was supported by National Institutes of Health Grants AG02049 (S.B.C.), DA021501 (M.R.A.), DC002167 (J.E.S.), and HD052083, and FRAXA (J.R.F.). We thank A. T. Hoogeveen, J. C. Darnell, D. L. Nelson, J. D. Richter, C Bagni, M. J. Fritzler, and M. F. Bear for generous gifts of reagents.

*S.B.C. and M.R.A. contributed equally to this work.

Correspondence should be addressed to Justin R. Fallon, Department of Neuroscience, Brown University, Box G-LN, Providence, RI 02912. E-mail: Justin_Fallon@brown.edu.

DOI:10.1523/JNEUROSCI.3937-08.2009

Copyright (C) 2009 Society for Neuroscience $\quad$ 0270-6474/09/291514-11\$15.00/0
mGluR-dependent long-term depression is also abnormal in these mutant animals (Huber et al., 2002). However, several lines of evidence suggest a potential axonal or presynaptic role. In Drosophila, mutations in the sole homolog $d f m r$ cause defects in axonal targeting and arborization, as well as misregulated presynaptic structure (Zhang et al., 2001; Michel et al., 2004). In rodents, FMRP is expressed in the axons of cultured hippocampal neurons, where its absence alters growth cone dynamics (Antar et al., 2006). Moreover, in axons of striatal GABAergic neurons, FMRP absence correlates with a dysregulation of GABA release (Centonze et al., 2008). Together, these observations suggest the hypothesis that FMRP has discrete functions during early developmental periods of robust synaptic formation and plasticity, and that some of these functions could involve a presynaptic locus of action. We have therefore assessed the expression of FMRP and its homologs, FXR1P and FXR2P, in the developing mammalian brain, with particular attention to potential axonal or presynaptic expression.

In agreement with earlier work, we observe that the three members of this protein family are expressed in the soma and proximal dendrite of virtually every neuron. However, FMRP, FXR1P, and FXR2P are also present in granules (FXGs) that are restricted to axons and the presynaptic apparatus in a subset of neural circuits. These FXGs are expressed during defined developmental epochs that correlate with periods of robust synaptic plasticity. Moreover, FXG expression is upregulated during reinnervation of lesioned olfactory glomeruli, with peak expression 

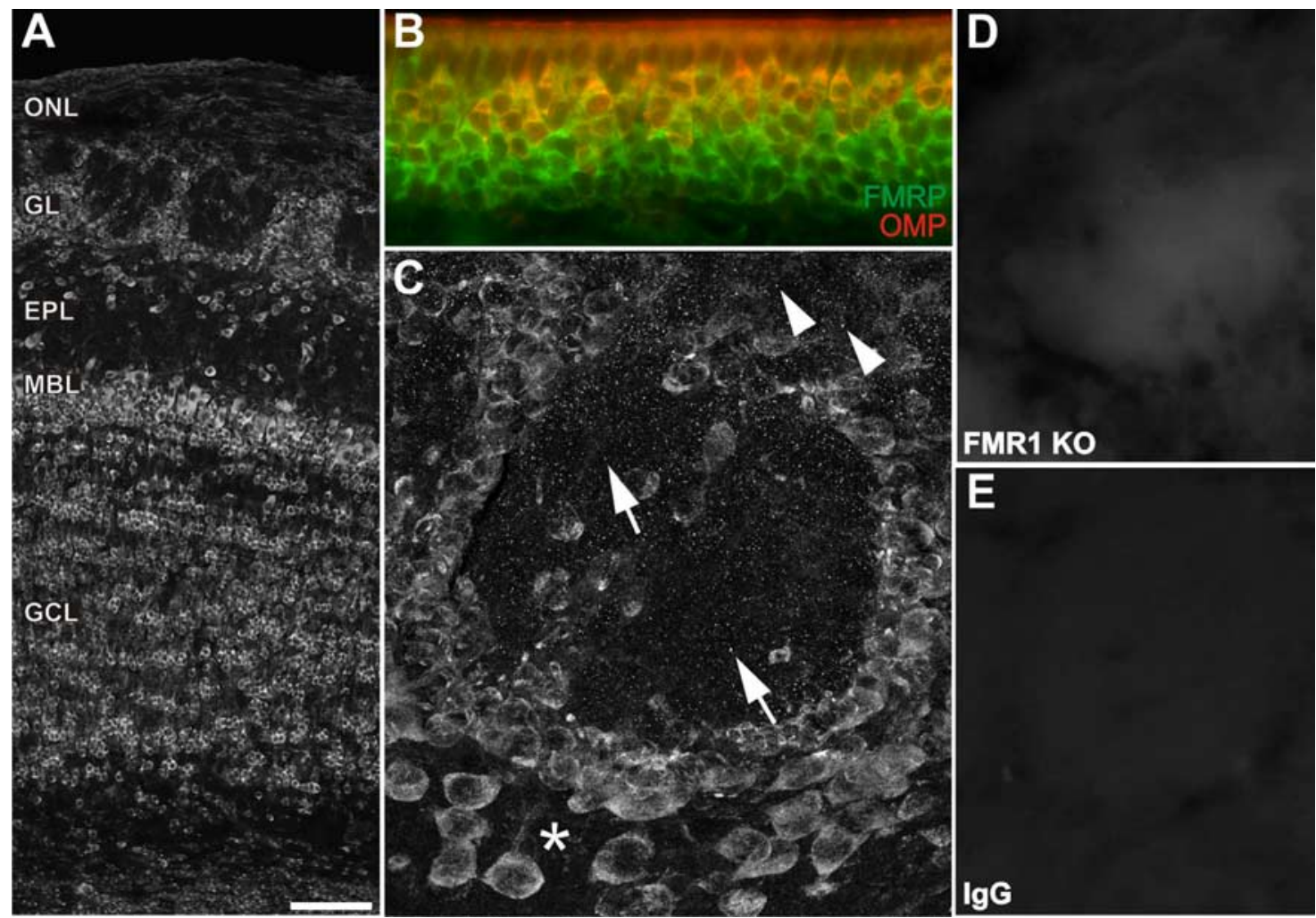

Figure 1. Two classes of FMRP-containing structures in the olfactory bulb. $A$, FMRP was expressed in the somata and proximal dendrites of all major neuron types in the olfactory bulb. $\boldsymbol{B}$, FMRP was expressed in olfactory sensory neuron somata in the olfactory epithelium (FMRP, green; OMP, red). C, High magnification of the glomerular layer revealed a second class of FMRP-containing structures, termed FXGs, that are discrete, granular, and selectively localized to the glomerular neuropil (arrows) and olfactory nerve layer (ONL) (arrowheads). Note that FXGs are not detected in the synapse-rich external plexiform layer (EPL; asterisk). Controls, Neither the somatodendritic staining nor FXGs were observed in experiments in which fmr 1 null mice sections were incubated with anti-FMRP antibody (D), or wild-type sections were labeled with an equal concentration of irrelevant lgG (E). GL, Glomerular layer; MBL, mitral cell body layer; GCL, granule cell layer. Scale bars: $\boldsymbol{A}$, $200 \mu \mathrm{m} ; \boldsymbol{B}-\mathbf{E}, 20 \mu \mathrm{m}$.

observed during the period of synaptic refinement. Genetic approaches revealed that FXG expression requires FXR2P, while loss of FMRP results in exaggerated and persistent FXG expression. Together, our findings suggest that the Fragile $\mathrm{X}$ protein family is likely to play a presynaptic role at a defined subset of synapses. The developmentally restricted pattern of expression suggests a function for presynaptic translation at these synapses during particularly plastic periods. Moreover, the neurological, cognitive and autistic defects in FXS may be due, at least in part, to abnormalities in the presynaptic compartment in these selected circuits.

\section{Materials and Methods}

Animals. C57BL/6 wild-type or fmr1 KO mice (Jackson Laboratories) were deeply anesthetized by Halothane inhalation before perfusion with ice-cold PBS, followed by $4 \%$ sucrose $/ 4 \%$ paraformaldehyde in PBS. Tissue from FXR2 null mice (Bontekoe et al., 2002) and matched wildtype controls was generously provided by Jennifer Darnell (The Rockefeller University, New York, NY). All work with animals was performed in accordance with protocols approved by Brown University Institutional Animal Care and Use Committee. After perfusion, animals were decapitated and intact brains were carefully removed and postfixed in 50 $\mathrm{ml}$ of $4 \%$ sucrose $/ 4 \%$ paraformaldehyde PBS overnight at $4^{\circ} \mathrm{C}$. Brains were then halved, and 2-3-mm-thick sagittal tissue slabs (from midline, to maximize sucrose penetration) were passed through graded sucrose/ PBS solutions to $30 \%(\mathrm{w} / \mathrm{v})$ over the course of $3 \mathrm{~d}$. Cryoprotected brain slabs were embedded in OCT medium by rapid freezing ( $15 \mathrm{~s}$ submersion in LN2 cooled isopentane) and stored at $-80^{\circ} \mathrm{C}$ until sectioned. Sagittal sections of OCT embedded brains were prepared using a Leica cryostat at $30 \mu \mathrm{m}$, and stored in PBS at $4^{\circ} \mathrm{C}$ until use for immunolabeling.
Antibodies. For labeling of FMRP, the following antibodies and concentrations were used: mAb 2F5-1 [1:1; raised against a H6 fusion of 1-200 aa human FMRP protein; A. Tartakoff, Case Western Reserve University, Cleveland, OH; Gabel et al. (2004)], mAb 1C3 (1:500; Millipore) or 7G1-1 (1:1; identifying amino acids 354-368 of human FMRP; Developmental Studies Hybridoma Bank). Unless otherwise noted, all figures use 2F5-1 for FMRP labeling. Double-label immunofluorescence was performed by incubation of $\mathrm{mAb} 2 \mathrm{~F} 5-1$ with the following antibodies and concentrations: rabbit anti-FXR2P (1:500; pAb1937) and antiFXR1P (1:100; pAb2107) were gifts from A. Hoogeveen (Erasmus University, Rotterdam, The Netherlands). Human antisera IC6 and 18033 to GW182 (Eystathioy et al., 2003; Moser et al., 2007) were a gift from Marvin Fritzler (University of Calgary, Calgary, Alberta, Canada). Rabbit antibodies to CYFIP1 (Napoli et al., 2008) and CPEB3 (Huang et al., 2006) were generous gifts from Claudia Bagni (Catholic University of Leuven, Leuven, Belgium) and Joel Richter (University of Massachusetts Medical School, Worcester, MA), respectively. We also used antibodies to calbindin (Millipore; 1:2500), olfactory marker protein (OMP) (Wako; 1:20,000) and MAP2 (Millipore, AB5622; 1:250). Secondary antibodies used were purchased from Invitrogen and were used to 1:1250 in the following pairs, depending on the species of primary antibodies used: Alexa 488 conjugated goat anti-mouse $\operatorname{IgG}(\mathrm{H}+\mathrm{L})$ and Alexa 546conjugated goat anti-rabbit $(\mathrm{H}+\mathrm{L})$ or Alexa 488 conjugated donkey antimouse $(\mathrm{H}+\mathrm{L})$.

Immunohistochemistry. Free-floating sections of tissue fixed as described above were incubated with $0.08 \% \mathrm{NaBH}_{4}$ for 15 min to decrease background autofluorescence, then washed twice for $2 \mathrm{~min}$ in PBS before antigen retrieval by incubation with mild agitation in $0.01 \mathrm{M}$ sodium citrate, $\mathrm{pH} 6.0$, at $75^{\circ} \mathrm{C}$ for $45 \mathrm{~min}$. This antigen retrieval step greatly increased the detection of FMRP in these tissue samples while allowing good preservation of morphology. Samples were then slowly cooled to 

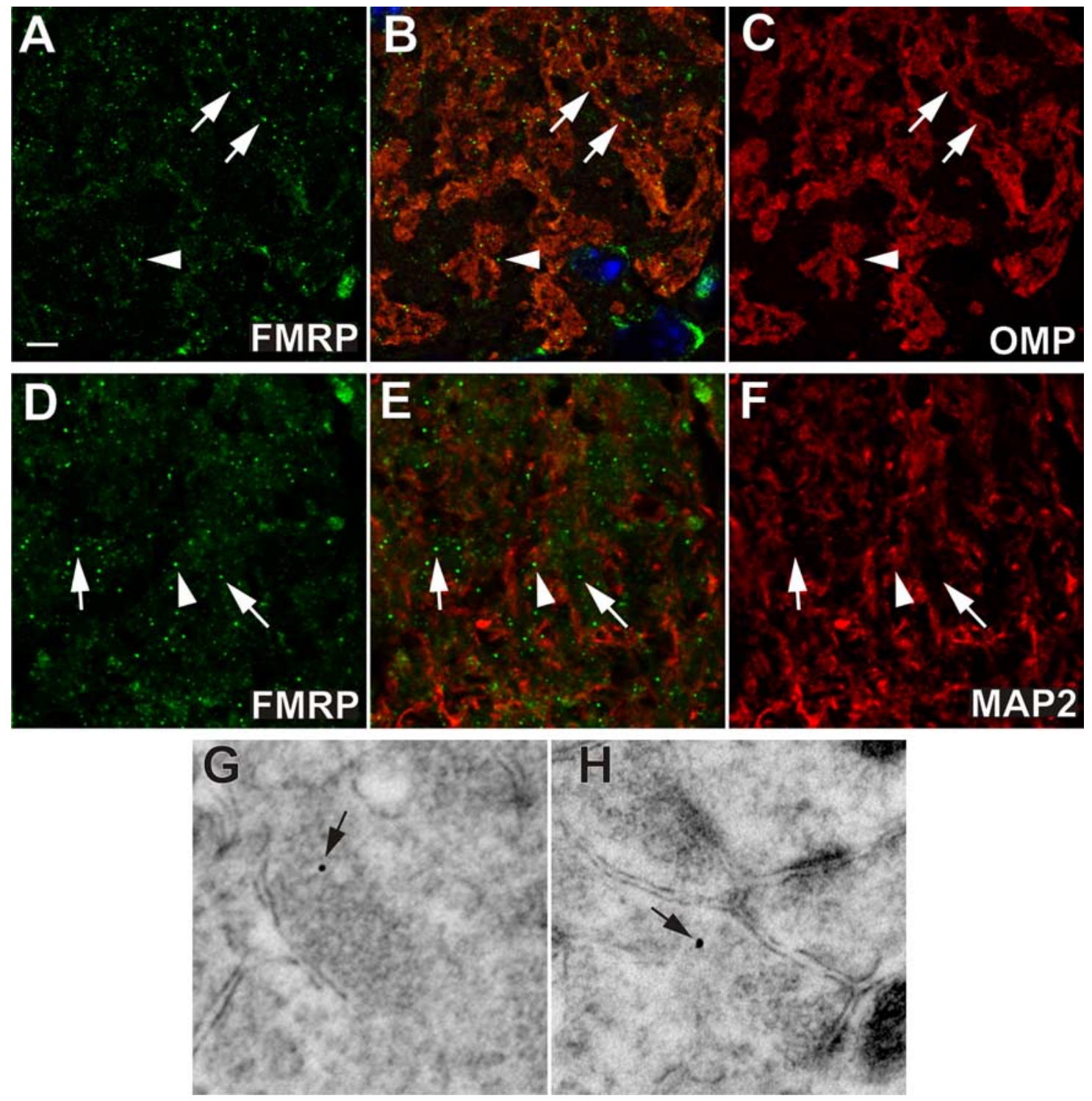

Figure 2. FXGs are expressed presynaptically in olfactory glomeruli. FXGs, containing FMRP (green, $\boldsymbol{A}, \boldsymbol{B}, \boldsymbol{D}, \boldsymbol{E}$ ), were enriched within OSN axonal domains (arrows, $\boldsymbol{A}-\boldsymbol{F}$ ) marked by 0MP (red, $\boldsymbol{B}$, C). Conversely, relatively few FXGs were observed in dendrite-rich domains (arrowheads, $\boldsymbol{A}-\boldsymbol{F}$ ) marked by MAP2 (red, $\boldsymbol{E}$ and $\boldsymbol{F}$ ). Immunogold electron microscopy showed that FMRP was localized in presynaptic specializations (arrow, $\boldsymbol{G}, \boldsymbol{H}$ ). Scale bars: $\boldsymbol{A}-\boldsymbol{F}, 10 \mu \mathrm{m} ; \boldsymbol{G}, \boldsymbol{H}, 90 \mathrm{~nm}$.

room temperature over $30 \mathrm{~min}$. After two PBS washes (2 min each), samples were processed for fluorescence immunocytochemistry using the Mouse on Mouse basic kit (M.O.M.; Vector Labs). Briefly, samples were incubated with M.O.M. blocking solution for $1 \mathrm{~h}$, washed twice with PBS and incubated with M.O.M. diluent solution for $10 \mathrm{~min}$ before overnight incubation at $4^{\circ} \mathrm{C}$ with antibodies in diluent. Sections were then washed three times for 15 min each with PBS before overnight incubation at $4^{\circ} \mathrm{C}$ with appropriate antibodies in diluent. Images were collected using either a Nikon Eclipse T800 microscope (objectives: $1 \times$ plan Acro, $40 \times$ plan Apo oil, $60 \times$ plan Apo oil) coupled with an Orca ER or 285 CCD (Hammamatsu) or a Leica or Zeiss laser-scanning confocal microscopes (objectives: $10 \times$ air and $63 \times$ oil). Figures were prepared using Photoshop 7.0 (Adobe) and CorelDraw X3 (Corel). When comparing signal between different conditions, images were acquired and processed under identical conditions. Graphs and statistical analyses were produced using Prism 5.0 (Graphpad).

Immunogold electron microscopy. Tissue was processed as above through the application of primary antibody (anti-FMRP mAb 2F5-1). Secondary detection was with a goat anti-mouse conjugated to Ultra Small gold (1:50; Aurion). We confirmed that the gold-tagged and fluorescently tagged secondary antibodies had equivalent access to the pri- mary antibody by visualizing the gold-conjugated secondary antibody with a donkey anti-goat Alexa546 tertiary antibody (data not shown). After three $2 \mathrm{~h}$ washes in PBS, the tissue was fixed in $2.5 \%$ glutaraldehyde in PBS for $2 \mathrm{~d}$ at $4^{\circ} \mathrm{C}$. The tissue was then rinsed several times with PBS followed by enhancement conditioning solution (ECS) (Aurion), and the immunogold label was silver-enhanced for 90 min using Aurion R-Gent SE-EM enhancement kit. The tissue was washed in ECS followed by $0.1 \mathrm{M}$ phosphate buffer and postfixed with $0.25 \%$ osmium tetroxide for $30 \mathrm{~min}$. After phosphate buffer washes, the tissue was dehydrated through a graded ethanol series and infiltrated with Spurr's epoxy resin. Sections $(50-60 \mathrm{~nm})$ were stained with uranyl acetate and lead citrate and examined using a Morgagni 268 transmission electron microscope equipped with an AMT Advantage 542 CCD camera system.

Immunogold particle counts. Sections from three animals (two wildtype, one fmr 1 knock-out) were analyzed for presence and distribution of silver-enhanced gold particles. All tissue used for counting was processed in parallel at the same time. The two wild-type samples included 161 images covering $1380 \mu \mathrm{m}^{2}$ and 159 images covering $2400 \mu \mathrm{m}^{2}$, respectively. The knock-out sample comprised 73 images covering $1984 \mu \mathrm{m}^{2}$. Assignments to presynaptic and postsynaptic specializations were based on proximity ( $<500 \mathrm{~nm}$ ) to vesicle pools or PSDs, respectively. Assign- 

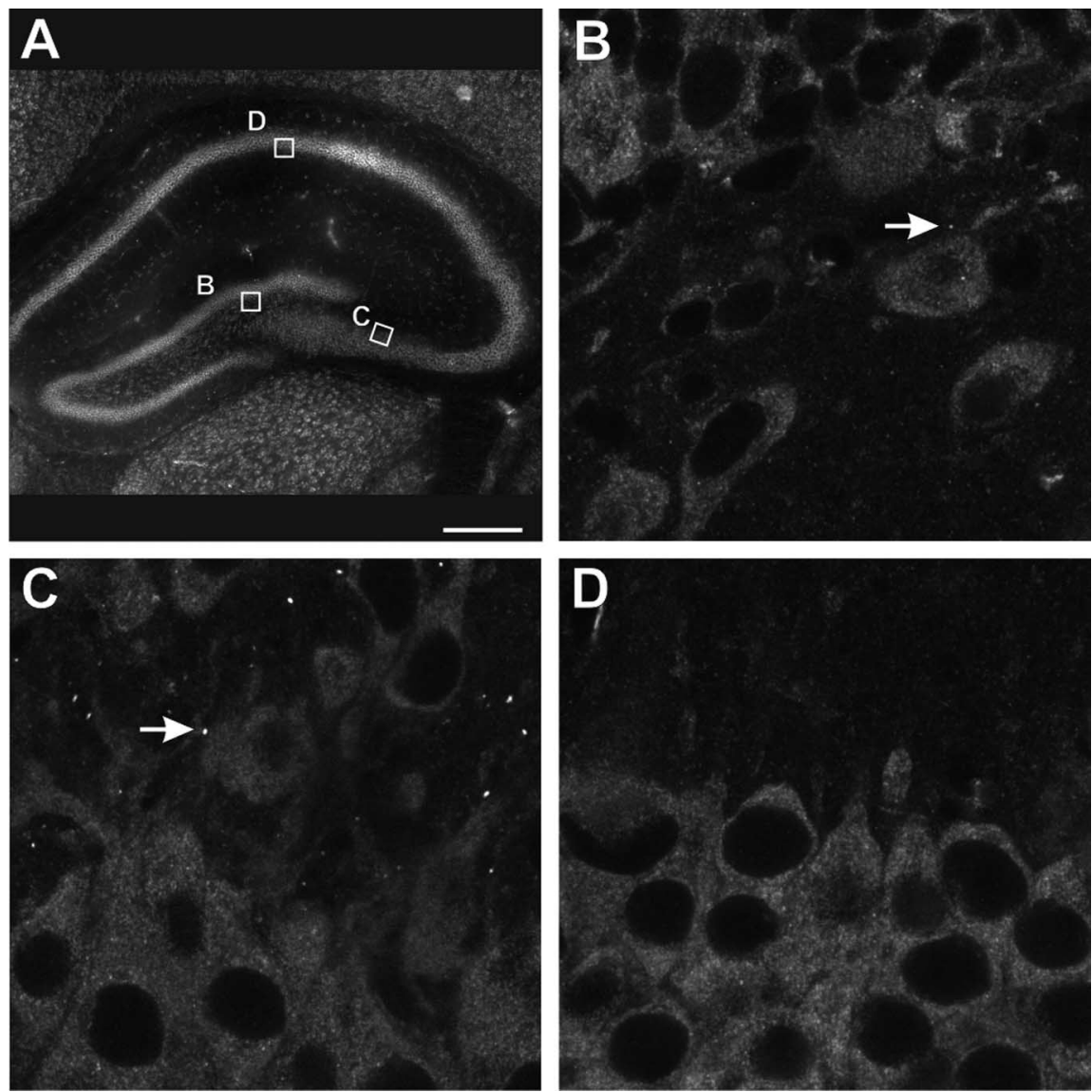

Figure 3. FXGs are expressed in the hilus of the dentate gyrus and CA3 but not in CA1. FMRP was expressed in the cell bodies and proximal dendrites of nearly all P15 hippocampal neurons ( $\boldsymbol{A}$; epifluorescence microscopy). FXGs (arrows) were relatively sparse in the hilus of the dentate gyrus $(\boldsymbol{B})$, with higher levels present in $C A 3(\boldsymbol{C})$. Strikingly, no FXGs were observed in area $(A 1$ (D). Boxes in $\boldsymbol{A}$ shown as confocal micrographs in $\boldsymbol{B}-\boldsymbol{D}$. Scale bars: $\boldsymbol{A}, 850 \mu \mathrm{m} ; \boldsymbol{B}-\boldsymbol{D}, 10 \mu \mathrm{m}$.

ment to axons and dendrites were based on a number of factors, including how electron lucent the process was, its orientation and thickness, whether it tapered or was continuous with a cell body, and the presence/ absence of presynaptic or postsynaptic specializations elsewhere in the visual field. Qualitatively similar results were observed in immunogoldlabeled sections from three additional wild-type brains.

Immunofluorescence granule counts. Sections from wild-type and fmrl knock-out animals were treated for immunostaining as detailed above. Images were sharpened in Photoshop to accentuate granules, with all images processed identically. Granules were counted manually, blinded to the condition. Granule counts were normalized to the total area of each collected image for cerebral cortex and hippocampus and to the area of the counted glomerulus for the olfactory bulb. For statistical analyses, $n=$ number of images or glomeruli, respectively. In the $f x r 2$ knock-out, no FXGs were observed in any brain region of three separate animals. Thus, no counts were performed in these animals.

Methyl bromide treatment. Male Sprague Dawley rats were obtained from Taconic at 225-250 g body weight and exposed to methyl bromide at 275-300 $\mathrm{g}$ in accordance with a previously published procedure (Schwob et al., 1995; Iwema et al., 2004). At various times after lesion, the rats were deeply anesthetized and perfused intracardially with phosphate-buffered $4 \%$ paraformaldehyde.

\section{Results}

FMRP is localized in axonal and presynaptic compartments

Since we were interested in the role of the Fragile X proteins during synaptic formation and plasticity, we first examined FMRP expression in the olfactory bulb, where axonal ingrowth and synapse formation persist throughout life (Graziadei and
Graziadei, 1979; Shepherd et al., 2004; Mombaerts, 2006). As shown in Figure $1 A$, FMRP was expressed in virtually all neurons of the olfactory bulb including the granule, mitral, tufted and juxtaglomerular cells. Within these cells, the protein was most highly concentrated in the somata and the most proximal portion of the dendrites. The prominent expression in the somata and proximal dendrites is in agreement with FMRP expression reported for other brain regions (Bakker et al., 2000; Hoogeveen et al., 2002; Gabel et al., 2004). FMRP was also expressed in the ensheathing cells of the olfactory nerve layer (Fig. $1 A$; supplemental Fig. S1 $A$, available at www.jneurosci.org as supplemental material). Examination of the olfactory epithelium showed that FMRP was expressed by both mature (OMP positive) and immature (OMP negative) olfactory sensory neurons (OSNs) (Fig. $1 B$ ).

Further examination revealed a second class of FMRP-immunoreactive structures in the olfactory bulb. As shown in Figure $1 C, \mathrm{FMRP}$ is expressed in discrete granules in the olfactory nerve layer and glomeruli. These FMRP-containing granules were remote from the cell body and were not observed in the external plexiform (Fig. 1C), mitral cell, internal plexiform, or granule cell layers (data not shown). As described in detail below, these FMRP-containing granules have several distinctive characteristics, including containing the FMRP homolog FXR2P (and in some regions FXR1P, see below). Therefore, we will refer to these structures as FXGs for the remainder of this report.

We performed a series of controls to verify the specificity of the FXG immunostaining. (1) FXGs were detected with antibodies 1C3, 7G1-1 and 2F5-1 (Fig. 1C; supplemental Fig. S1, available at www.jneurosci.org as supplemental material), each of which recognizes distinct epitopes on FMRP (Devys et al., 1993; Ceman et al., 2003; Gabel et al., 2004). (2) None of the anti-FMRP antibodies recognized FXGs in sections from Fmr1 null brains (Fig. 1D) (data not shown). (3) The lack of 2F5-1 immunostaining in the Fmr1 null tissue is in agreement with our previous Western blotting data showing that this antibody recognizes FMRP and does not cross react with FXR1P or FXR2P (Gabel et al., 2004). 4) No signal was observed if an irrelevant $\operatorname{IgG}$ was substituted for 2F5-1 (Fig. 1E). Together, these results establish that FMRP is a bona fide constituent of FXGs.

The localization of FXGs in the olfactory nerve layer and glomeruli suggested an axonal and perhaps synaptic localization of FMRP. As a first test of this idea, we compared the localization of the FXGs to OMP, which in the olfactory bulb is expressed exclusively in olfactory sensory neuron axons. Figure $2 A-C$ shows that FXGs are enriched in OMP-positive axonal subcompartments (arrows). In contrast, few FXGs were detected in dendritic subcompartments (marked by MAP2 immunoreactivity) (Fig. $2 D$, $E$, arrowheads). Notably, the FXGs were preferentially localized to the border between axonal and dendritic domains, the site of axodendritic synapses in the olfactory bulb (Kasowski et al., 
1999). These immunofluorescence observations show that FXGs are selectively enriched in axonal subcompartments of the olfactory glomeruli and are consistent with their expression at synapses.

To determine the precise subcellular localization of FMRP we turned to ultrastructural analysis. Detection of the goldconjugated secondary with a fluorescent antibody indicated that this labeling was consistent with the labeling we saw at the light level (see Materials and Methods). Additionally, gold particles were observed only rarely in fmr1 knock-out mice (see below). Immunogold electron microscopy showed that FMRP is expressed presynaptically, with gold particles often observed in synaptic vesicle-rich domains (Fig. $2 G, H$, arrows). Consistent with this presynaptic localization, FMRP immunoreactivity was also observed in axons of the olfactory nerve layer (supplemental Fig. S2A, available at www.jneurosci.org as supplemental material). FMRP labeling, at lower levels, was also associated with postsynaptic elements (supplemental Fig. $\mathrm{S} 3 A$, available at www.jneurosci.org as supplemental material). These observations demonstrate that FMRP is expressed in axons and in the presynaptic compartment in olfactory glomeruli.

\section{Presynaptic, circuit-selective expression of FXGs in the hippocampus}

We next examined FXG expression in the hippocampus, where synaptic organization is ordered and well defined. Genetic and electrophysiological studies have also demonstrated an important role for FMRP in this brain region (Huber et al., 2002; Nosyreva and Huber, 2005, 2006). We first surveyed the hippocampus at postnatal day 15 (P15), the period of peak synaptogenesis and plasticity (Harris et al., 1992; Fiala et al., 1998). FMRP is expressed in the somatodendritic domain of neurons in all hippocampal areas (Fig. 3A). In contrast, FXG distribution was restricted to the hilus of the dentate gyrus and area CA3 (Fig. $3 B, C$; supplemental Fig. $\mathrm{S} 4 A$, available at www. jneurosci.org as supplemental material). In CA3, FXGs were expressed in the neuropil of the strata pyramidale (Fig. $4 \mathrm{~A}$ ), lucidum and oriens (see below). Within strata pyramidale and lucidum the FXG distribution mirrors the mossy fiber projection of the dentate gyrus granule cells. In support of this assignment, FXGs are colocalized with calbindin D-28K, which is expressed by mossy fiber terminals but not by CA3 pyramidal cells (Sloviter, 1989) (Fig. 4B). Interestingly, the polymorphic area of the dentate gyrus, through which the initial portion of the mossy fiber axons synapse and/or project, had relatively few FXGs (Fig. 3B). This restricted distribution suggests a tight regulation in the localization of the FXGs to the zone in which mossy fiber synapses are present.

The close association and colocalization of FXGs with the calbindin-positive mossy fiber axons prompted us to examine this area of the hippocampus at the ultrastructural level. Immu- nogold electron microscopy of the proximal CA3 region revealed both presynaptic (Fig. 4C) and postsynaptic (supplemental Fig. $\mathrm{S} 3 B$, available at www.jneurosci.org as supplemental material) FMRP localization. The specificity of the immunogold was labeling was confirmed by quantifying gold particles in sections from fmr1 null tissue (gold particle density of 0.18 and 0.24 particles per $\mu \mathrm{m}^{2}$ in two wild-type animals; compared with 0.0071 particles per $\mu \mathrm{m}^{2}$ in a knock-out animal) (see also Fig. $4 D$; supplemental Fig. S5, available at www.jneurosci.org as supplemental material). We next quantified FMRP localization by counting the number of silver-enhanced gold particles within CA3 stratum pyramidale of P30 mice (Fig. 4D). FMRP immunogold particles were prominently localized to mossy fiber synapses, which made up a relatively small proportion of the total area examined. In each animal examined, these particles were more abundant at mossy fiber presynaptic terminals than at postsynaptic sites (Fig. $4 D$ ). Consistent with our observations at the immunofluorescence level, gold particles were detected within somatic, dendritic and axonal compartments (supplemental Fig. S5, available at www.jneurosci.org as supplemental material). Thus FMRP is localized to the presynaptic compartment in hippocampal area CA3. 

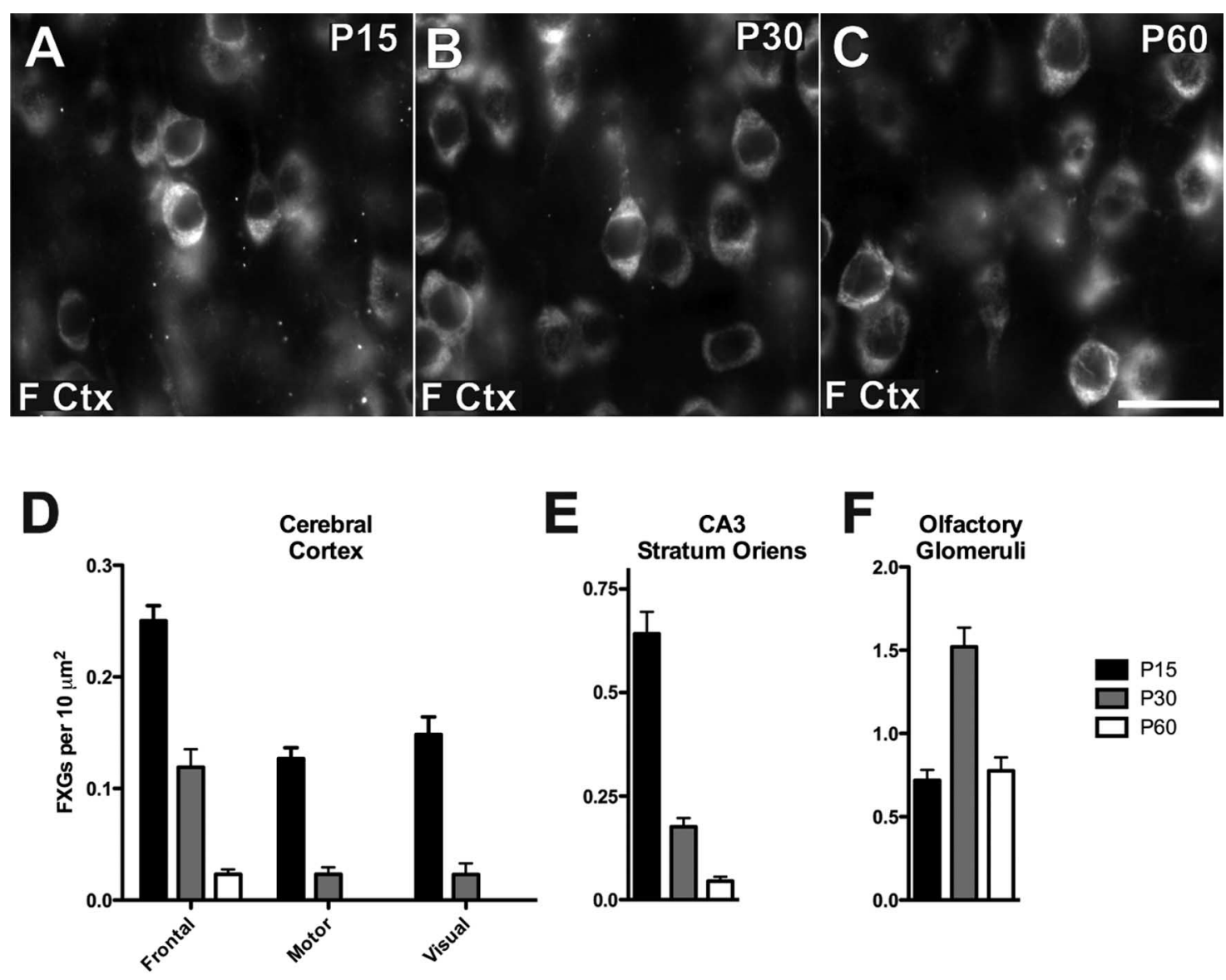

Figure 5. FXG density is dynamically regulated during development. FXG expression was assessed at three developmental epochs: juvenile (P15), sexual maturation (P30) and adult (P60). In frontal cortex $(\boldsymbol{A}-\boldsymbol{C}, \boldsymbol{D})$, motor cortex $(\boldsymbol{D})$, visual cortex $(\boldsymbol{D})$, and $C A 3$ stratum oriens $(\boldsymbol{E})$, a steady decline in granule density from juvenile to adult was observed. FXG density in frontal cortex declined from $0.25 \pm 0.01 \mathrm{FXGs}$ per $10 \mu \mathrm{m}^{2}(n=13)$ at P15 to $0.119 \pm 0.016(n=13)$ at P30 and $0.023 \pm 0.004(n=11)$ at P60. Motor cortex density declined from $0.127 \pm 0.010(n=6)$ at P15 to $0.023 \pm 0.006(n=6)$ at P30. Visual cortex decreased from $0.148 \pm 0.016(n=6)$ at P15 to $0.023 \pm 0.010(n=5)$ at P30. Stratum oriens of CA3 declined from $0.642 \pm 0.053(n=14)$ at P15, to $0.176 \pm 0.021(n=12)$ at P30 and $0.045 \pm 0.010(n=10)$ at P60. In contrast, FXG density in the olfactory bulb at P15 was $0.718 \pm 0.063(n=39)$, followed by a peak of $1.52 \pm 0.12(n=$ 42) at P30, and subsequently a decline to $0.776 \pm 0.081(n=38)$ at P60. Number of animals: 3 for P15 frontal cortex and hippocampus; 2 for all other points. Scale bar, $20 \mu \mathrm{m}$. Values expressed as mean \pm SEM.

We next asked whether FXGs are restricted to mossy fibers in CA3. In the stratum oriens of the CA3 field, FXGs were observed in a band beginning at the border of the outer blade of the dentate gyrus and extending partially into the fimbria (supplemental Fig. S4A, available at www.jneurosci.org as supplemental material) (data not shown). Immunogold electron microscopy confirmed that FMRP is associated with axons in stratum oriens (supplemental Fig. S2 B, available at www.jneurosci.org as supplemental material). Interestingly, there was no association of FXGs with the occasional calbindin-labeled mossy fiber axons that were present in the stratum oriens (data not shown). Thus, FXGs are present in a nonmossy fiber axonal population in stratum oriens.

Remarkably, FXGs were not observed in the rest of the hippocampus. We did not detect FXGs in CA1 (Fig. 3D) or in the inner molecular layer of the dentate gyrus at any of the examined ages (P7-P160). In accord with these observations, presynaptic immunogold labeling was not detected in these structures (data not shown). Together, these data indicate that presynaptic FMRP is present in a subset of neural circuits within the hippocampus.

Region- and layer-selective expression of FXGs in the cerebral cortex

A survey of the cerebral cortex in the parasagittal plane at P15 revealed that FXGs are enriched in the frontal compared with the motor and visual cortices (Fig. 5D; supplemental Fig. S4 $B-D$, available at www.jneurosci.org as supplemental material). FXGs were most abundant in the neuropil between resident layer neuronal cell bodies in layers V and VI (supplemental Fig. S4 $B-D$, available at www.jneurosci.org as supplemental material), were not detected in layer I, and were present at low levels in layers II-IV (data not shown). As in other brain regions, somatodendritic FMRP was detected in neurons in all layers and in all regions of cerebral cortex examined (supplemental Fig. $\$ 4 B-D$, available at www.jneurosci.org as supplemental material) (data not shown). Thus FXGs show both a region- and layer-selective expression in the cerebral cortex.

\section{FXGs are developmentally regulated in cerebral cortex,} hippocampus, and cerebellum

We next sought to determine whether FXGs are present throughout life or are characteristic of a defined developmental epoch. We surveyed FMRP expression in parasagittal sections of P15, P30 and P60 brains and quantified FXG density in deep cortical layers and in CA3 stratum oriens. FXG density was tenfold higher in P15 compared with P60 frontal cortex. Examination of P150 mouse brain confirmed this developmental trend: virtually no FMRP granules were detected at this age (data not shown). FXG density in both motor and visual cortex as well as CA3 stratum 
oriens also decreased with age (Fig. 5D,E). This developmental regulation of FXG expression was also observed within the mossy fiber terminal field of CA3 stratum pyramidale (data not shown).

FXGs were also observed in the superficial molecular layer of the developing cerebellum, just deep to the external granule layer (P15) (supplemental Fig. S6 A, D, available at www.jneurosci.org as supplemental material). This location is where newly born granule cells are extending their axons and forming synapses (Landis, 1987). Consistent with this, FXGs were seen to appose calbindin-expressing Purkinje cell dendrites (supplemental Fig. S7, available at www.jneurosci.org as supplemental material). FXGs were also detected in this location at P6 and P20 (data not shown). No FXGs were observed in cerebellum after the disappearance of the external granule layer (P30) (supplemental Fig. $\mathrm{S} 6 B, E$, available at www.jneurosci.org as supplemental material) or in mature animals (P60) (supplemental Fig. S6C,F, available at www.jneurosci.org as supplemental material). Together, these observations indicate that in neocortical, hippocampal, and cerebellar brain regions FXG expression is restricted to a discrete developmental time window.

\section{FXG expression in olfactory glomeruli parallels synaptic maturation}

The developmental profile of FXG expression in the olfactory bulb was unique among the brain regions studied: high levels were detected throughout the life of the animal (Fig. 5F). The distinctive FXG expression pattern in olfactory bulb could reflect the natural history of this brain region: OSNs turn over at a high rate throughout life. The persistence of FXGs in the adult olfactory glomeruli thus raised the possibility that FXG expression might correspond to a particular epoch during which synapses made by these newly born neurons are forming and/or maturing. To test this hypothesis, we took advantage of the regenerative capacity of the olfactory epithelium. Exposing rats to methyl bromide gas ablates $90-95 \%$ of olfactory sensory neurons, resulting in wholesale glomerular deafferentation (Schwob et al., 1995). Regenerating neurons then project axons to the olfactory bulb and form new synapses in the glomeruli in a synchronized manner. Figure 6 shows that methyl bromide-induced ablation of OSNs resulted in an initial decline in FXG density in the olfactory glomeruli (6-fold lower than controls at 10d postlesion; $p<0.01$, Dunnett's $t$ test). This reduction in FXGs correlates with the loss of innervation in the glomeruli at this time (Schwob et al., 1999). FXG density then increased, with a 2.5 -fold "overshoot" peak observed at 4 weeks after treatment ( $p<0.01$, Dunnett's $t$ test). FXG levels returned to baseline by 5 weeks. Previous studies have shown that OSN axon outgrowth to the olfactory bulb is largely complete by 3 weeks postlesion. At 4 weeks, there is massive glomerular innervation and OSN maturation (Schwob et al., 1995, 1999). Thus FXG expression in this regenerating CNS neuropil is correlated with the period of synapse formation and refinement.

\section{FXG composition}

As a first step toward characterizing the molecular composition of FXGs, we asked whether they also contain the FMRP homologs FXR1P and FXR2P. The three Fragile X proteins constitute a family of RNA-binding proteins that are also capable of associating with one another (Corbin et al., 1997). Double immunofluorescence showed that FXR2P is a component of virtually all FXGs in all brain regions examined (Table 1). In hippocampus, the large majority of FXGs contained both FXR2P and FMRP, with relatively few harboring FXR1P (Table 1) (data not shown).

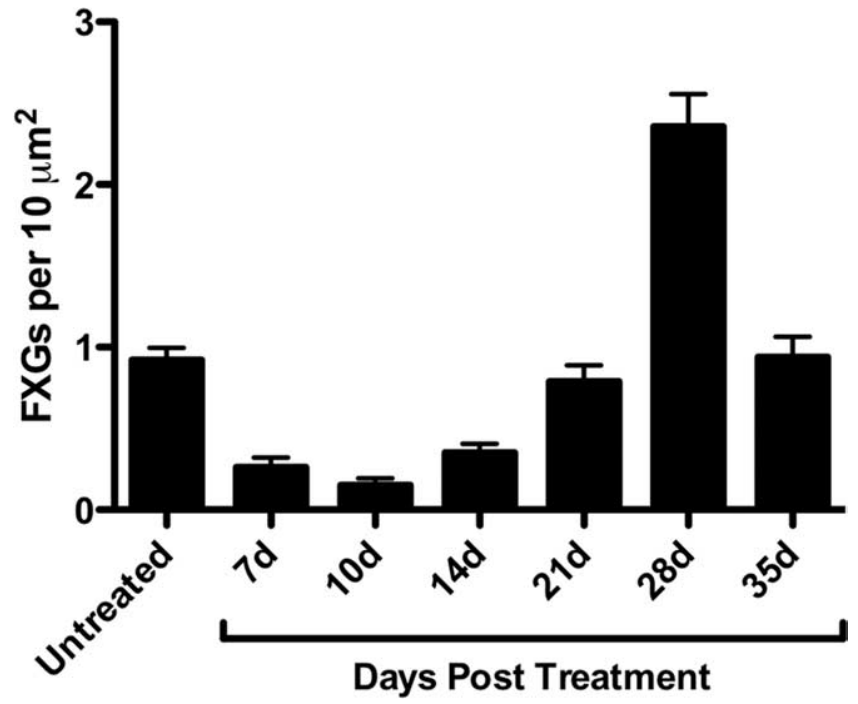

Figure 6. FXG density during innervation and synaptogenesis in the regenerating olfactory system. Adult rats were treated with methyl bromide ( $\mathrm{MeBr}$ ), which ablates the olfactory epithelium and results in synchronized reinnervation and reformation of synaptic circuitry in the olfactory bulb (Schwob et al., 1995, 1999). FXG density was measured in olfactory glomeruli in untreated controls and at the indicated days post treatment (DPT). Control animals had $0.922 \pm 0.075 \mathrm{FXGs}$ per $10 \mu \mathrm{m}^{2}(n=61)$. At 7 and $10 \mathrm{DPT}$, as axons in the glomeruli are dying, the numbers fell to $0.261 \pm 0.061(n=21)$ and $0.151 \pm 0.043(n=21)$, respectively. By 14 DPT, as axonal reinnervation of the glomeruli is beginning, levels rose to $0.352 \pm 0.054(n=$ 35). At $21 \mathrm{DPT}$, as glomerular reinnervation is largely complete, levels rose to $0.789 \pm 0.100$ $(n=37)$. By 28 DPT, as axons are integrating into the circuit, FXG density rose to $2.36 \pm 0.20$ $(n=41)$. Levels returned to baseline by 35 DPT $(0.938 \pm 0.127 ; n=24)$. MeBr treatment had a significant effect on FXG density ( $p<0.001$, ANOVA). FXG density was significantly different from controls at 7, 10, 14, and 28 DPT ( $p<0.01$, Dunnett's $t$ test). Number of animals: 4 for control, 14 DPT, 21 DPT, and 28 DPT; 2 for all other points. Values expressed as mean \pm SEM.

In olfactory bulb, virtually all FXGs contained FXR2P and FMRP, with a subset also containing FXR1P (Table 1) (data not shown). All three family members were detected in the majority of FXGs in frontal cortex (Fig. 7; Table 1). FXR1P was also prominent in nucleoli and was observed in a separate class of granules that did not contain FMRP (Fig. 7A-C, arrowhead). FXGs contained no detectable GW182, CYFIP1 or CPEB3, although all these antigens were readily observed in the somatodendritic domain (supplemental Fig. S8, available at www.jneurosci.org as supplemental material). Together, these findings indicate that all FXGs contain FXR2P, with subpopulations containing FMRP and/or FXR1P.

\section{FXR2P is required for FXG formation}

As FXR2P is a component of essentially every FXG, we hypothesized that it might be critical for FXG formation. To test this idea we examined tissue from $f x r 2$ null mice. Staining in the somatodendritic compartment for FMRP (Fig. 8C) in the cerebral cortex was indistinguishable from wildtype (Fig. 8A). However, no FXGs were observed in these fxr2 null mice (Fig. $8 C$ ). These results demonstrate that FXR2P is necessary for FXG formation and that FMRP cannot compensate for its absence.

\section{FMRP regulates FXG number}

To assess the role of FMRP in FXG expression we examined fmr 1 null mice. Somatodendritic expression of FXR2P was not detectably altered in these mutant mice (Fig. 8D) compared with wild types (Fig. $8 B$ ). Strikingly, immunostaining with FXR2P (Fig. $8 D$ ) revealed that FXGs are expressed in fmrl null mice. However, FXG expression was dysregulated in the absence of FMRP. 

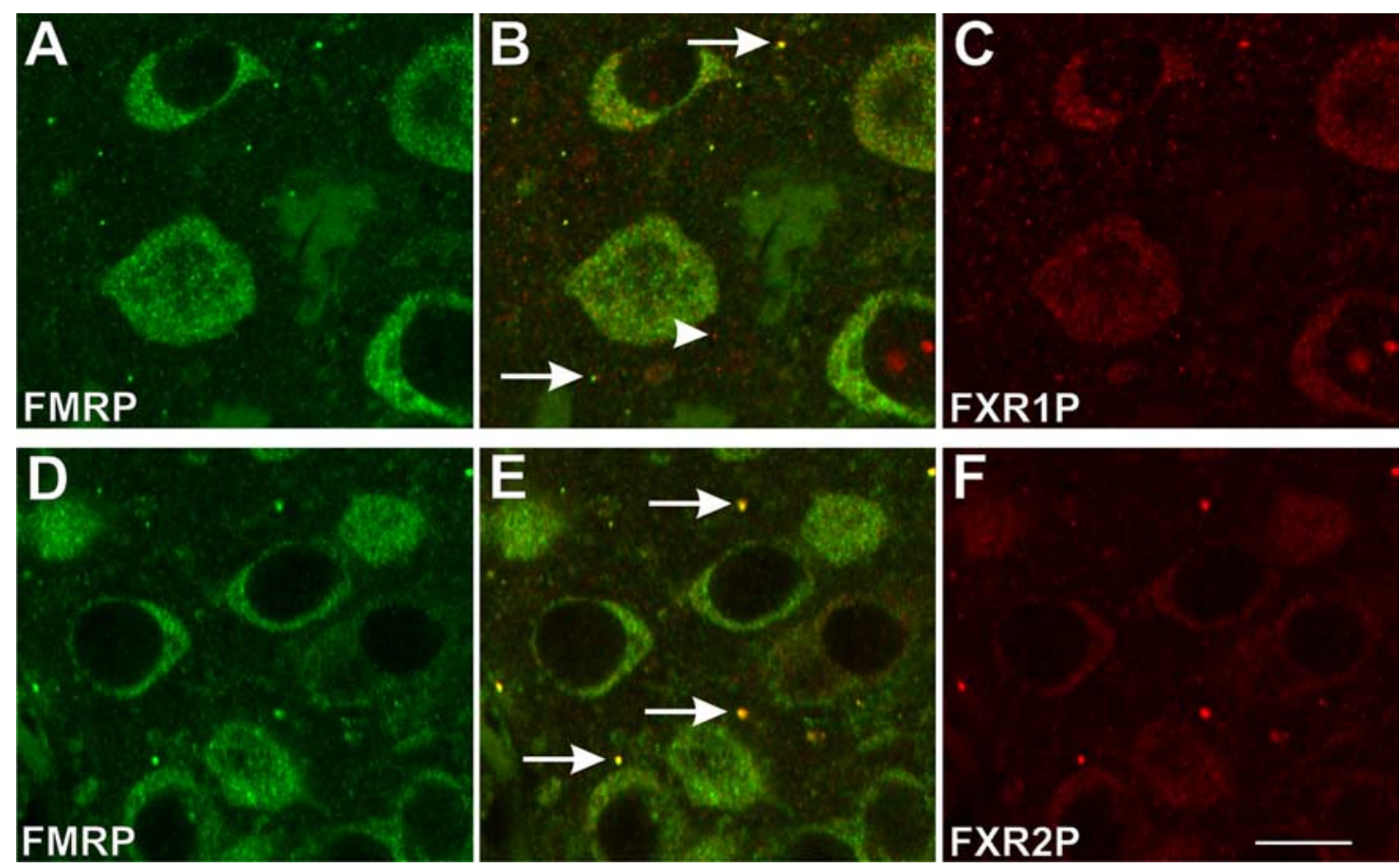

Figure 7. FXG composition in frontal cortex. Confocal micrographs of P15 frontal cortex. FXGs contain FMRP (green; $A, B, D, E), F X R 1 P($ red; $B, C$ ), and FXR2P (red; $E, F)$. FXR1P, in addition to its somatic staining, colocalizes with FMRP in the FXGs (arrows, $\boldsymbol{B}$ ) and is also present in additional granules that do not contain FMRP (arrowhead, $\boldsymbol{B}$ ). FXR2P is expressed most strongly in FMRP-containing FXGs (arrows, $\boldsymbol{E}$ ) with comparatively weak somatic staining. Scale bar, $10 \mu \mathrm{m}$.

Table 1. Genetic analysis of FXG composition and regulation

\begin{tabular}{|c|c|c|c|c|c|c|}
\hline \multirow[b]{2}{*}{ Localization } & \multicolumn{2}{|l|}{ Wild-type } & \multicolumn{2}{|l|}{ Fmr1 null } & \multicolumn{2}{|l|}{ Fxr2 null } \\
\hline & Somatodendritic & FXG & Somatodendritic & FXG & Somatodendritic & FXG \\
\hline FMRP & + & + & - & - & + & - \\
\hline FXR1P & + & + & + & ++ & + & - \\
\hline FXR2P & + & + & + & ++ & - & - \\
\hline
\end{tabular}

+ , Present at wild-type levels; ++ , density of granules upregulated relative to wild-type levels; - , not detected. FMRP, FXR1P, and FXR2P, were expressed in the somatodendritic region of virtually all wild-type neurons. FXGs were only detected in a subset of brain regions. FXR1P was predominantly restricted to FXGs in the cerebral cortex. See Results for details.

While the region-specific pattern of FXG expression remained unchanged, the density within these brain areas was increased. Quantification of FXG density using FXR2P staining in wild-type and $f m r 1$ knock-out mice revealed that there were 4.1-fold more FXGs at P15 and 3.5-fold more FXGs at P30 in the fmr1 knockout than in the control (Fig. $8 E$ ). Together, these data show that FXR2P and FMRP play discrete roles in FXG expression and regulation.

\section{Discussion}

The most striking features of FXGs are their localization to axonal and presynaptic compartments, restriction to a subset of brain circuits during defined developmental periods, absolute dependence on FXR2P and regulation by FMRP. All of these attributes distinguish FXGs from the ubiquitous pool of Fragile X proteins investing the somatodendritic domain. Here, we will discuss the evidence supporting the assignment of FXGs as a novel context for Fragile X proteins and the implications of these findings for FXS and autism.

Several lines of evidence support the conclusion that FXGs are predominantly localized to the axonal and presynaptic compartments of selected neurons. (1) FXGs are most abundant in neuropil, e.g., strata oriens and lucidum in hippocampal area CA3 as well as the glomeruli of the olfactory bulb (Figs. 1-4). (2) FXGs are also observed in the axons in the hilus of the hippocampus and in the olfactory nerve layer (Fig. 3B; supplemental Fig. S1, available at www.jneurosci.org as supplemental material). (3) FXGs are enriched in the axonal/presynaptic compartments compared with dendritic domains of the olfactory glomerulus (Fig. 2). (4) The number of FXGs in the olfactory glomerulus drops precipitously after ablation of olfactory sensory neurons (Fig. 6). (5) Immunoelectron microscopy shows that FMRP is localized presynaptically in olfactory glomeruli (Fig. 2) and in hippocampal area CA3 (Fig. 4). Importantly, we could detect postsynaptic FMRP by immunoelectron microscopy in many brain regions including olfactory glomeruli (Fig. 2), hippocampal areas CA3 (Fig. 4) and CA1 (data not shown). However, we only observed presynaptic FMRP in those areas where FXGs were observed (e.g., olfactory glomeruli and area CA3). An earlier ultrastructural study (Feng et al., 1997) also reported postsynaptic and "rare" presynaptic FMRP in cerebral cortex, which is consistent with our immunohistochemical observations in this brain region (Fig. 5A-D; supplemental Fig. $\mathrm{S} 3 B-D$, available at www. jneurosci.org as supplemental material). Thus, FXGs correlate with presynaptic and axonal localization of the Fragile X proteins.

Several studies have provided evidence that local protein synthesis in growth cones can play a role in axonal growth and guidance (Willis et al., 2007; Cox et al., 2008; Lin and Holt, 2008). Moreover, FMRP has been localized to growth cones in cultured neurons (Antar et al., 2006). However, we saw little evidence for FXG localization in growth cones in the systems examined here. For example, FXG number in regenerating olfactory circuits peaked at the time of synapse formation and refinement, rather than during the earlier phase characterized by axonal growth 

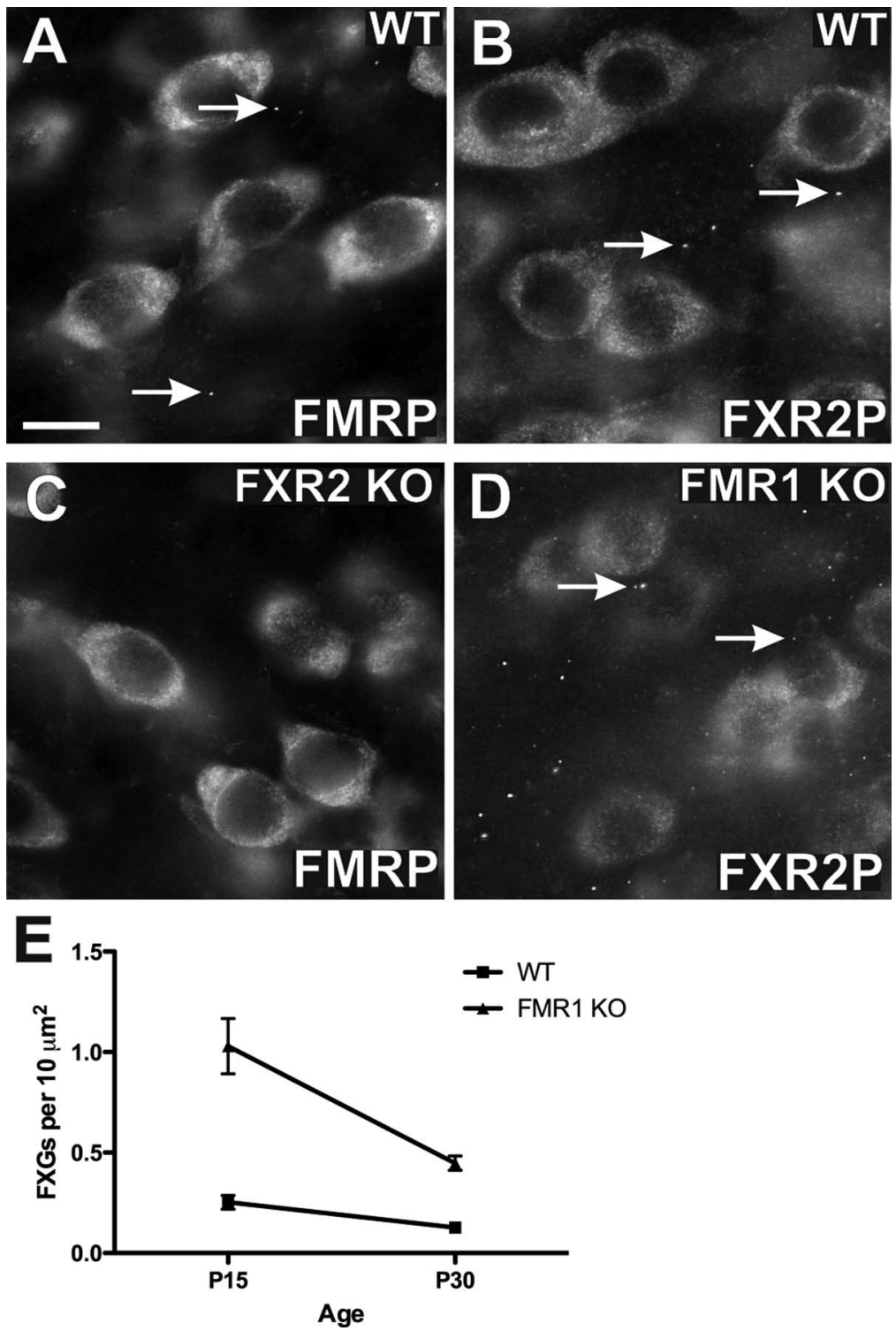

Figure 8. FXR2P and FMRP differentially regulate FXG expression. FXGs were detected in P30 wild-type frontal cortex as seen by FMRP ( $\boldsymbol{A}$, arrows) and FXR2P ( $\boldsymbol{B}$, arrows). In age-matched fxr2 knock-out mice, no FXGs were detected with anti-FMRP ( $\boldsymbol{C}$. In age-matched fmr 1 knock-out mice, a significant increase in FXR2P-containing FXGs was observed (arrows, D). Quantitation of FXR2P granules in P15 and P30 frontal cortex $(\boldsymbol{E})$ showed that FXG density in fmr $1 \mathrm{~K} 0$ mice at $\mathrm{P} 15$ was $1.03 \pm 0.25 \mathrm{FXGs}$ per 10 $\mu \mathrm{m}^{2}(n=9)$ compared with $0.253 \pm 0.034(n=9)$ in wildtype. FXG density in fmr $1 \mathrm{KO}$ mice at P30 was $0.447 \pm 0.036(n=$ 9 ) compared with $0.127 \pm 0.013$ in wildtype $(n=9)$. Values expressed as mean \pm SEM. A two-way ANOVA confirmed an effect for both age ( $p<0.001)$ and genotype ( $p<0.001)$, as well as an interaction between the two $(p<0.01)$. Number of animals: 4 for the P15 time points, 3 for the P30 time points. Scale bar, $10 \mu \mathrm{m}$.

(Fig. 6). Moreover, we observed few FXGs in area CA3 at P7, a time when growth cones are abundant. It is important to stress that these observations in no way preclude a role for non-FXGassociated Fragile X proteins in growth cones and axonal guidance. Indeed, there is little doubt that the Fragile $\mathrm{X}$ proteins are components of a variety of complexes (Jin et al., 2004; Zalfa et al., 2006), each of which is likely to carry out distinct functions within the cell.

The functions of FXGs at the presynaptic apparatus are not known, but one attractive idea is that they are involved in translation-dependent synaptic plasticity. Such presynaptic plasticity has been observed in cultured neurons for BDNF-mediated potentiation and for serotonin-induced long term facilitation (Zhang and Poo, 2002; Lyles et al., 2006). The molecular mecha- nisms acting in these cases are not known. Mutations of $d f m r 1$, the sole homolog of the Fragile $\mathrm{X}$ gene family in Drosophila, lead to abnormal structure and function of the larval neuromuscular junction. Genetic experiments indicate at least some of this role is in the presynaptic cell, potentially through interaction with MAP1b message (Zhang et al., 2001). Notably, several of the known mRNA targets of mammalian FMRP encode proteins active in the presynaptic apparatus including Munc13, semaphorin 3F, NAP-22, SEC-7, RAB-5, ID3 and Cadherin 11 (Brown et al., 2001; Miyashiro et al., 2003).

The developmental regulation of FXGs may reflect a linkage between neurogenesis and the expression of these granules. In hippocampal area CA3 as well as in cerebral cortex, FXG expression peaks at approximately P15 and then falls off rapidly, with almost no FXGs detected after P60 (Fig. 5). Dentate granule neurons, which form the FXG-rich mossy fiber terminals in area CA3, show peak neurogenesis around P7 (Bayer and Altman, 1974; Schlessinger et al., 1975). In the developing cerebellar cortex, FXGs are only detected during the developmental time window when granule cells are born, migrate and make initial synaptic contacts with Purkinje cells (P6-P20) (supplemental Fig. $\mathrm{S} 5$, available at www.jneurosci.org as supplemental material) (Miale and Sidman, 1961; Altman, 1969). Finally, the time course of FXG expression during regeneration of OSN afferents showed a similar discrete window of peak expression after neurogenesis (Fig. 6) (Schwob et al., 1995). Together, these results argue that FXGs are expressed as newly generated neurons are making their initial synaptic contacts.

It should be noted that most neuronal types express few if any FXGs, regardless of developmental stage. For example, olfactory granule cells are born throughout life, but we did not detect FXGs in the external plexiform layer, where these cells form synapses (Fig. 1). Furthermore, FXGs were not detected in hippocampal area CA1 at P7 or P15. Together, these results suggest that FXG expression is a function of both neuron age and type.

Our morphological and genetic experiments provide insights into the mechanisms of FXG formation and regulation. All FXGs express FXR2P (Figs. 7, 8). Furthermore, FXR2P is necessary for FXG formation in all brain regions examined (Fig. 8). In contrast, FMRP is not required for FXG formation, but serves as a negative regulator of their expression (Fig. 8). Interestingly, while FMRP regulates the number and timing of FXG expression, its loss has no effect on the neuronal cell-type specificity of FXG expression. We were unable to test the role of FXR1P in depth, since mutants in this gene die at birth (Mientjes et al., 2004), and this protein is present in multiple types of granules (Fig. 7). Nonetheless, the 
absence of FXR1P in most hippocampal and olfactory bulb FXGs of either wild-type or fmrl mutants suggests that this member of the Fragile X family may play a less prominent role in these structures. Finally, the levels of FMRP and FXR2P in the somatodendritic compartment were unaffected in the fxr2 and fmr1 mutants, respectively (Fig. 8) (see also Bakker et al., 2000). Thus, the mechanisms underlying Fragile X protein expression in FXGs are distinct from those in the somatodendritic compartment.

Fmr1 mutations cause FXS and are the most common single gene basis for autism. A host of recent studies support the view that both FXS and autism spectrum disorders are synaptic diseases (Huber et al., 2002; Zoghbi, 2003; Moretti et al., 2006; Chao et al., 2007; Morrow et al., 2008). Although the nature of the synaptic abnormalities are likely to be diverse, it seems likely that many of these defects will involve experience-dependent plasticity in selected neural circuits during development. For example, over $50 \%$ of autistic patients show regression, where they are apparently normal until $\sim 2$ years of age. Moreover, the bestcharacterized physical sign of autism spectrum disorder is a transiently enlarged brain during early childhood, which might reflect a deficit in axonal pruning (Aylward et al., 1999; Courchesne et al., 2003). Pruning defects, which must involve presynaptic elements, are also characteristic of FXS (Irwin et al., 2001). We suggest that presynaptic defects, at least in part involving the FXG pathway, could be relevant to the etiology and treatment of FXS and autism.

\section{References}

Altman J (1969) Autoradiographic and histological studies of postnatal neurogenesis. 3. Dating the time of production and onset of differentiation of cerebellar microneurons in rats. J Comp Neurol 136:269-293.

Antar LN, Li C, Zhang H, Carroll RC, Bassell GJ (2006) Local functions for FMRP in axon growth cone motility and activity-dependent regulation of filopodia and spine synapses. Mol Cell Neurosci 32:37-48.

Aylward EH, Minshew NJ, Goldstein G, Honeycutt NA, Augustine AM, Yates KO, Barta PE, Pearlson GD (1999) MRI volumes of amygdala and hippocampus in non-mentally retarded autistic adolescents and adults. Neurology 53:2145-2150.

Bakker CE, de Diego Otero Y, Bontekoe C, Raghoe P, Luteijn T, Hoogeveen AT, Oostra BA, Willemsen R (2000) Immunocytochemical and biochemical characterization of FMRP, FXR1P, and FXR2P in the mouse. Exp Cell Res 258:162-170.

Bayer SA, Altman J (1974) Hippocampal development in the rat: cytogenesis and morphogenesis examined with autoradiography and low-level X-irradiation. J Comp Neurol 158:55-79.

Bontekoe CJ, McIlwain KL, Nieuwenhuizen IM, Yuva-Paylor LA, Nellis A, Willemsen R, Fang Z, Kirkpatrick L, Bakker CE, McAninch R, Cheng NC, Merriweather M, Hoogeveen AT, Nelson D, Paylor R, Oostra BA (2002) Knockout mouse model for Fxr2: a model for mental retardation. Hum Mol Genet 11:487-498.

Brown V, Jin P, Ceman S, Darnell JC, O'Donnell WT, Tenenbaum SA, Jin X, Feng Y, Wilkinson KD, Keene JD, Darnell RB, Warren ST (2001) Microarray identification of FMRP-associated brain mRNAs and altered mRNA translational profiles in fragile X syndrome. Cell 107:477-487.

Ceman S, Zhang F, Johnson T, Warren ST (2003) Development and characterization of antibodies that immunoprecipitate the FMR1 protein. Methods Mol Biol 217:345-354.

Centonze D, Rossi S, Mercaldo V, Napoli I, Ciotti MT, De Chiara V, Musella A, Prosperetti C, Calabresi P, Bernardi G, Bagni C (2008) Abnormal striatal GABA transmission in the mouse model for the fragile X syndrome. Biol Psychiatry 63:963-973.

Chao HT, Zoghbi HY, Rosenmund C (2007) MeCP2 controls excitatory synaptic strength by regulating glutamatergic synapse number. Neuron 56:58-65.

Corbin F, Bouillon M, Fortin A, Morin S, Rousseau F, Khandjian EW (1997) The fragile $\mathrm{X}$ mental retardation protein is associated with poly(A)+ mRNA in actively translating polyribosomes. Hum Mol Genet 6:1465-1472.
Courchesne E, Carper R, Akshoomoff N (2003) Evidence of brain overgrowth in the first year of life in autism. JAMA 290:337-344.

Cox LJ, Hengst U, Gurskaya NG, Lukyanov KA, Jaffrey SR (2008) Intraaxonal translation and retrograde trafficking of CREB promotes neuronal survival. Nat Cell Biol 10:149-159.

Devys D, Lutz Y, Rouyer N, Bellocq JP, Mandel JL (1993) The FMR-1 protein is cytoplasmic, most abundant in neurons and appears normal in carriers of a fragile X premutation. Nat Genet 4:335-340.

Eystathioy T, Chan EK, Mahler M, Luft LM, Fritzler ML, Fritzler MJ (2003) A panel of monoclonal antibodies to cytoplasmic GW bodies and the mRNA binding protein GW182. Hybrid Hybridomics 22:79-86.

Feng Y, Gutekunst CA, Eberhart DE, Yi H, Warren ST, Hersch SM (1997) Fragile X mental retardation protein: nucleocytoplasmic shuttling and association with somatodendritic ribosomes. J Neurosci 17:1539-1547.

Fiala JC, Feinberg M, Popov V, Harris KM (1998) Synaptogenesis via dendritic filopodia in developing hippocampal area CA1. J Neurosci 18:8900-8911.

Gabel LA, Won S, Kawai H, McKinney M, Tartakoff AM, Fallon JR (2004) Visual experience regulates transient expression and dendritic localization of fragile X mental retardation protein. J Neurosci 24:10579-10583.

Graziadei PP, Graziadei GA (1979) Neurogenesis and neuron regeneration in the olfactory system of mammals. I. Morphological aspects of differentiation and structural organization of the olfactory sensory neurons. J Neurocytol 8:1-18.

Harris KM, Jensen FE, Tsao B (1992) Three-dimensional structure of dendritic spines and synapses in rat hippocampus (CA1) at postnatal day 15 and adult ages: implications for the maturation of synaptic physiology and long-term potentiation. J Neurosci 12:2685-2705.

Hoogeveen AT, Willemsen R, Oostra BA (2002) Fragile X syndrome, the Fragile X related proteins, and animal models. Microsc Res Tech 57:148-155.

Huang YS, Kan MC, Lin CL, Richter JD (2006) CPEB3 and CPEB4 in neurons: analysis of RNA-binding specificity and translational control of AMPA receptor GluR2 mRNA. EMBO J 25:4865-4876.

Huber KM, Gallagher SM, Warren ST, Bear MF (2002) Altered synaptic plasticity in a mouse model of fragile X mental retardation. Proc Natl Acad Sci U S A 99:7746-7750.

Irwin SA, Patel B, Idupulapati M, Harris JB, Crisostomo RA, Larsen BP, Kooy F, Willems PJ, Cras P, Kozlowski PB, Swain RA, Weiler IJ, Greenough WT (2001) Abnormal dendritic spine characteristics in the temporal and visual cortices of patients with fragile-X syndrome: a quantitative examination. Am J Med Genet 98:161-167.

Iwema CL, Fang H, Kurtz DB, Youngentob SL, Schwob JE (2004) Odorant receptor expression patterns are restored in lesion-recovered rat olfactory epithelium. J Neurosci 24:356-369.

Jin P, Zarnescu DC, Ceman S, Nakamoto M, Mowrey J, Jongens TA, Nelson DL, Moses K, Warren ST (2004) Biochemical and genetic interaction between the fragile X mental retardation protein and the microRNA pathway. Nat Neurosci 7:113-117.

Kasowski HJ, Kim H, Greer CA (1999) Compartmental organization of the olfactory bulb glomerulus. J Comp Neurol 407:261-274.

Landis DMD (1987) Initial junctions between developing parallel fibers and Purkinje cells are different from mature synaptic junctions. J Comp Neurol 260:513-525.

Lin AC, Holt CE (2008) Function and regulation of local axonal translation. Curr Opin Neurobiol 18:60-68.

Lyles V, Zhao Y, Martin KC (2006) Synapse formation and mRNA localization in cultured aplysia neurons. Neuron 49:349-356.

Miale IL, Sidman RL (1961) An autoradiographic analysis of histogenesis in the mouse cerebellum. Exp Neurol 4:277-296.

Michel CI, Kraft R, Restifo LL (2004) Defective neuronal development in the mushroom bodies of Drosophila fragile X mental retardation $1 \mathrm{mu}-$ tants. J Neurosci 24:5798-5809.

Mientjes EJ, Willemsen R, Kirkpatrick LL, Nieuwenhuizen IM, HoogeveenWesterveld M, Verweij M, Reis S, Bardoni B, Hoogeveen AT, Oostra BA, Nelson DL (2004) Fxrl knockout mice show a striated muscle phenotype: implications for Fxrlp function in vivo. Hum Mol Genet 13:1291-1302.

Miyashiro KY, Beckel-Mitchener A, Purk TP, Becker KG, Barret T, Liu L, Carbonetto S, Weiler IJ, Greenough WT, Eberwine J (2003) RNA cargoes associating with FMRP reveal deficits in cellular functioning in Fmr 1 null mice. Neuron 37:417-431. 
Mombaerts P (2006) Axonal wiring in the mouse olfactory system. Annu Rev Cell Dev Biol 22:713-737.

Moretti P, Levenson JM, Battaglia F, Atkinson R, Teague R, Antalffy B, Armstrong D, Arancio O, Sweatt JD, Zoghbi HY (2006) Learning and memory and synaptic plasticity are impaired in a mouse model of Rett syndrome. J Neurosci 26:319-327.

Morrow EM, Yoo SY, Flavell SW, Kim TK, Lin Y, Hill RS, Mukaddes NM, Balkhy S, Gascon G, Hashmi A, Al-Saad S, Ware J, Joseph RM, Greenblatt R, Gleason D, Ertelt JA, Apse KA, Bodell A, Partlow JN, Barry B, et al. (2008) Identifying autism loci and genes by tracing recent shared ancestry. Science 321:218-223.

Moser JJ, Eystathioy T, Chan EK, Fritzler MJ (2007) Markers of mRNA stabilization and degradation, and RNAi within astrocytoma GW bodies. J Neurosci Res 85:3619-3631.

Napoli I, Mercaldo V, Boyl PP, Eleuteri B, Zalfa F, De Rubeis S, Di Marino D, Mohr E, Massimi M, Falconi M, Witke W, Costa-Mattioli M, Sonenberg N, Achsel T, Bagni C (2008) The fragile X syndrome protein represses activity-dependent translation through CYFIP1, a New 4E-BP. Cell 134:1042-1054.

Nosyreva ED, Huber KM (2005) Developmental switch in synaptic mechanisms of hippocampal metabotropic glutamate receptor-dependent longterm depression. J Neurosci 25:2992-3001.

Nosyreva ED, Huber KM (2006) Metabotropic receptor-dependent longterm depression persists in the absence of protein synthesis in the mouse model of fragile X syndrome. J Neurophysiol 95:3291-3295.

O'Donnell WT, Warren ST (2002) A decade of molecular studies of fragile X syndrome. Annu Rev Neurosci 25:315-338.

Pickett J, London E (2005) The neuropathology of autism: a review. J Neuropathol Exp Neurol 64:925-935.

Schlessinger AR, Cowan WM, Gottlieb DI (1975) An autoradiographic study of the time of origin and the pattern of granule cell migration in the dentate gyrus of the rat. J Comp Neurol 159:149-175.

Schwob JE, Youngentob SL, Mezza RC (1995) Reconstitution of the rat olfactory epithelium after methyl bromide-induced lesion. J Comp Neurol 359:15-37.

Schwob JE, Youngentob SL, Ring G, Iwema CL, Mezza RC (1999) Reinnervation of the rat olfactory bulb after methyl bromide-induced lesion: timing and extent of reinnervation. J Comp Neurol 412:439-457.

Shepherd GM, Chen WR, Greer CA (2004) Olfactory bulb. In: The synaptic organization of the brain (Shepherd GM, ed), pp 165-216. New York: Oxford UP.

Sloviter RS (1989) Calcium-binding protein (calbindin-D28k) and parvalbumin immunocytochemistry: localization in the rat hippocampus with specific reference to the selective vulnerability of hippocampal neurons to seizure activity. J Comp Neurol 280:183-196.

Willis DE, van Niekerk EA, Sasaki Y, Mesngon M, Merianda TT, Williams GG, Kendall M, Smith DS, Bassell GJ, Twiss JL (2007) Extracellular stimuli specifically regulate localized levels of individual neuronal mRNAs. J Cell Biol 178:965-980.

Zalfa F, Achsel T, Bagni C (2006) mRNPs, polysomes or granules: FMRP in neuronal protein synthesis. Curr Opin Neurobiol 16:265-269.

Zhang X, Poo MM (2002) Localized synaptic potentiation by BDNF requires local protein synthesis in the developing axon. Neuron 36:675-688.

Zhang YQ, Bailey AM, Matthies HJ, Renden RB, Smith MA, Speese SD, Rubin GM, Broadie K (2001) Drosophila fragile X-related gene regulates the MAP1B homolog futsch to control synaptic structure and function. Cell 107:591-603

Zoghbi HY (2003) Postnatal neurodevelopmental disorders: meeting at the Synapse? Science 302:826-830. 